\title{
Labia usted La Educación Médica en un mundo en proceso de globalización
}

\author{
Profesor Andrzej Wojtczak MD., PhD
}

\section{bidy in Globalizing World}

Las palabras de apertura de Sir Lionel Whit, Presidente de la Asociación Médica Mundial, en la Primera Conferencia Mundial en Educación Médica en 1953 en Londres, dijo: "El mundo ... se ha encogido tanto... que ya no podemos tener una visión provinciana de nuestros problemas". Cincuenta años más tarde continuamos pensando que la educación médica se encuentra en el umbral de un cambio en profundidad. Este sentimiento de hecho tiene poco que ver con la autoreflexión de los expertos (en inglés, scholars) tratándose más bien de una consecuencia directa del proceso de globalización que, habiendo penetrado en casi todas las áreas de nuestra vida, ha comportado un perfil diferente de médico.

¿Necesitamos más evidencias de globalización de la medicina que las recientes epidemias de SARS y la gripe aviaria? Se inician en un parte distante del mundo y rápidamente alarman el planeta. Para combatir estas enfermedades se involucraron expertos y laboratorios de todo el mundo. No hay que olvidar que cada vez más, médicos y científicos de todas las nacionalidades, forman parte de una red global virtual que atiende a una población global según unos conocimientos y prácticas universales. Nos enfrentamos a retos como la diseminación del SIDA/HIV y otras enfermedades infecciosas que continúan matando unos 17 millones de personas al año. A esto se le suma el aumento de la movilidad de los médicos a nivel mundial lo que supone ver la necesidad de un "médico global".

Se estima que alrededor de un $25 \%$ de los médicos formados en África probablemente emigrarán a países desarrollados y un $50 \%$ de los licenciados de Lituania se desplazarán a trabajar a otros países. Así pues, se espera que
In opening address Sir Lionel Whit, President of the World Medical As-sociation at the First World Conference on Medical Education in 1953 in London said: „The world ...has become so shrunken...that we can no longer take parochial view of our problems". Fifty years later we also think that the medical education stands at the doorsteps of profound changes. This feeling in fact has less to do with scholars' self-reflection, but rather is a direct con-sequence of the process of globalization that has penetrated almost all areas of our life and what mandate a different kind of physician.

Do we need more evidence of globalization of medicine than recent epi-demics of SARS and bird flu? They began in a distant part of the world and have quickly alarmed the globe. In combat of this diseases were involved experts and laboratories from all over the world. It is a good reminder that physicians and scientists of every nationality are increasingly part of global virtual network expected to serve a global public in accordance with certain universal knowledge and practices. We face also other challenges such as spread of HIV/AIDS and other infectious diseases are still killing about 17 million people yearly. To add to that increased mobility of doctors world-wide we see a need for the "global doctor".

It is estimated that about $25 \%$ of doctors trained in

1. Publicados en español en Educación Médica Volumen 7, Suplemento 2 (Julio-Septiembre 2004)

2. Publicados en español en Educación Médica Volumen 6, Suplemento 2 (Julio-Septiembre 2003) 
las facultades de medicina de todos los países produzcan licenciados que satisfagan estas expectativas. Pero es verdad que casi 2000 facultades de medicina de todo el mundo están produciendo médicos cuyas competencias difieren considerablemente. En consecuencia, no podemos obviar la necesidad de definir unos estándares globales que especificarían el núcleo (en inglés, core) de conocimientos, habilidades, comportamientos y valores universales que garanticen que los licenciados han adquirido unas competencias equiparables independientemente de dónde han sido formados.

Disponer de unos estándares internacionales y globalmente aceptados, permitiría comparar la evaluación de las competencias profesionales de los licenciados, ya que hay que tener presente que la medicina, además de ser una ciencia, responde también a unos patrones culturales.

Esta definición de las competencias también ayudaría a indicar qué se supone que los docentes deberían enseñar, y lo que los estudiantes deberían aprender y qué experiencias educativas deberían tener todos los médicos del mundo. Por otro lado, las facultades de medicina están expresando el deseo de demostrar que los médicos que han formado son profesionales competentes. En los últimos años, expertos internacionales en educación médica, han desarrollado dos conjuntos de estándares globales de educación médica complementarios:

1. Los estándares de la Federación Mundial en Educación Médica (acrónimo en inglés, WFME) desarrollados para la acreditación de las facultades de medicina , y

2. Los Requisitos Globales Mínimos Esenciales en educación médica (acrónimo en inglés, GMER) y instrumentos de medida del Instituto para la Educación Médica Internacional (acrónimo en inglés, IIME) para evaluar las competencias requeridas de los licenciados.

Ambos conjuntos de estándares deberían servir a nivel global, para evaluar la calidad de las facultades de medicina y de sus productos.

La introducción reciente de las TIC (tecnologías de la información y la comunicación) abre nuevas posibilidades en el desarrollo de redes para la educación médica e investigación multicéntricas a escala global.

Un buen ejemplo en esta línea es IVIMEDS, colaboración mundial de facultades de medicina y otras instituciones, que trabajan para desarrollar el pleno potencial de la educación online a lo largo de la formación de pregrado.

Finalmente, merece la pena decir que dentro del marco de 20 conferencias internacionales, organizadas en los últimos dos años, se han tratado los aspectos relativos a la educación médica en un mundo globalizado. A tener presente el que ha sido uno de los mensajes más importantes, a saber, la constatación que el dominio de la realidad presente no prepara a los estudiantes para los retos que depara el futuro. Debemos prepararlos para que sepan manejar los cambios futuros.
Africa are likely to migrate to developed countries and $50 \%$ Lithuanian graduates move to work in other countries. So, the medical schools in all countries are expected to produce graduates that meet these expectations. But truth is that nearly 2000 medical schools worldwide are producing doctors whose competences differ very much. Consequently, we can not neglect an urgent need for defining the global standards that would specify the "core" knowledge, skills, behavior of the universal values to ensure that graduates regardless of where they are educated have similar competences. As medicine is not only scientific but also cultural pursuit it requires internationally developed standards that would be acceptable globally and would permit for assessment of professional com-petences of graduates.

Such defined competences would also help indicate what teachers are supposed to teach, what students are expected to learn and what educational experiences all physicians across world must have. On the other hand, the medical schools are expressing desirability to demonstrate that doctors they train are competent practitioners. In last few years, two sets of complemen-tary global medical education standards were developed by international medical education experts. The WFME International Standards developed for accreditation of medical schools, and the IIME "Global Minimum Essential Requirements" (GMER) and measurement tools to assess required competen-cies of graduates. Both might serve globally to evaluate quality of medical schools and their products.

The recent introduction of telematics creates new possibilities in the de-velopment of networks for multi-center medical education and research on a global scale. A good example of such development is IVIMEDS - the world-wide partnership of medical schools and institutions working together to develop the full potential of elearning across the continuum of medical school education.

Finally, it is worthwhile to say that the issues of medical education in a globalizing world were discussed at more than 20 international conferences organized in last two years around the world. One of its important messages to be remembered is that mastering the reality of today does not prepare stu-dents for the challenges of tomorrow - we have to prepare them how to man-age future changes. 